\title{
TÖRÖK ÁDÁM
}

\section{A brexit közbenső állapota}

Volt egyszer egy kvantumelméleti gondolatkísérlet, amely a „sem élö, sem holt” jellegü átmeneti állapotok megjelenítéséhez, a filozófiai érdeklődésüek számára pedig a bennük való metafizikai elmélyedéshez adott szemléletes eszközt. Ezt a gondolatkísérletet ma Erwin Schrödinger macskamodelljeként ismerjük. Ez a tanulmány a brexit elemzéséhez próbál kiindulni a macskamodellből. A brexit folyamata megkezdődött ugyan a 2016. júniusi brit népszavazással, jogi értelemben azonban valójában még nem is létezik. 2016 őszén ugyan várható, hogy a brit kormány 2017-ben elindítja majd a kiválás folyamatát, korántsem biztos azonban, hogy ezt a folyamatot belátható időn belïl le is lehet zárni. Többek között azért, mert nem látható olyan kereskedelempolitikai modell, amely mindkét felet kielégítené. Például nem látszik kivitelezhetőnek, hogy az Egyesült Királyság az egységes európai piac keretei között maradna, az EU viszont elérné a munkaerőpiac nyitottságának megtartását. A két fél kompromisszumos stratégiája könnyen a halogatás lehet: folyamatosan hangsúlyozhatnák, hogy a brexit megkezdődött, miközben fenntartják az integráció 2016 elötti állapotát. Így pedig évekig fennmaradhatna a 2016-ban egyelőre megfigyelhető átmeneti macskaszituáció. Journal of Economic Literature (JEL) kód: F13, F15.

A brexit nem is világosan meghatározott fogalom. A brexitről szóló népszavazás csak kezdeményezte, szigorú jogi értelmezésben pedig csupán ajánlotta az Egyesült Királyság kiválását az EU-ból, a brexit folyamata azonban ezzel még nem feltétlenül indult el. Hol tart akkor a folyamat? Vannak, akik már most „brexit utáni helyzetről” vagy „2016. június 23-i brexitről” beszélnek, de ez nyilván nem igaz. Természetesen nem védhető jól az az álláspont sem, amely szerint a brexit ügyében eddig nem is történt semmi visszafordíthatatlan. Könnyen lehet, hogy valahol a két álláspont között van az igazság, azt viszont eléggé nehéz lenne leírni a közgazdaságtanban gyakran alkalmazott bináris (igaz-hamis) logikával.

* Köszönet illeti Konka Boglárkát igen hasznos és alapos segítségéért. A tanulmány irodalomfeldolgozási módszere eltér a szokásostól: a brexit elötörténete egyelöre igen rövid, így kevés tudományos forrás áll rendelkezésre a folyamatról. A tanulmány szerzője ezért alig támaszkodhatott tudományos cikkekre, helyettük szakpolitikai elemzéseket, szakértői anyagokat és műhelytanulmányokat kellett felhasználnia.

Török Ádám akadémikus, egyetemi tanár, Pannon Egyetem és BME (e-mail: torok.adam@yahoo.com). A kézirat első változata 2016. november 16-án érkezett szerkesztőségünkbe.

DOI: http://dx.doi.org/10.18414/KSZ.2017.1.1 
Egy 20. század eleji metafizikai gondolatkísérletre támaszkodva próbáljuk megvilágítani a problémát. A kísérlet főszereplöje egy macska, és az 1933-as év fizikai Nobel-díjasa, Erwin Schrödinger találta ki. A „Schrödinger macskája” kvantumelméleti modelljét más természettudományi vagy társadalmi folyamatok ábrázolására is használják akkor, ha egy rendszer párhuzamos állapotait kívánják szemléltetni. Lényege, hogy egy macskát olyan dobozba zárnak, amelyben elhelyeztek egy halálos nukleáris dózis felszabadítására alkalmas csapot, de a doboz belseje kívülről nem látható. Azt sem lehet tudni, mikor nyílik ki a csap; a macska állapotáról csak a doboz kinyitásakor lehet meggyőződni. Így azt sem lehet tudni egy adott pillanatban, hogy a macska él-e még, vagy már nem (Hofstadter [1985] 468. o.).

A macskamodell egyik széles körben ismert értelmezése szerint a doboz lezárása és kinyitása közötti időben egyaránt lehetséges, hogy egyszerre két állapot létezik, és az is, hogy egy sem. Egy másik megközelítés pedig feltételezi egy harmadik állapot lehetőségét. Ez a harmadik állapot valahol a két szélső állapot között létezik, de távolsága egyiktől sem mérhető, sőt nem is definiálható. Ebben a feltételezett harmadik állapotban a macska már nem él, de még nem is élettelen.

A brexit a macskamodell érdekes nemzetközi gazdaságtani alkalmazását kínálhatja. A népszavazás látszólag lezárta a dobozt, de elképzelhető, hogy váratlanul létrejön egy olyan nemzetközi érdekkoalíció, amely közös erővel próbálja majd halogatni a doboz kinyitását - ha egyáltalán tényleg zárva van. ${ }^{1}$

A következőkben a brexit folyamatának néhány, egyelöre nem jól felmérhető, de a folyamatot valószínűleg hátráltató elemét próbáljuk megragadni. Következményük nemcsak a brexit késlekedése lehet, hanem akár az is, hogy a folyamat végül félbemarad valamilyen formában (a macskamodell „harmadik állapota”). Más szóval: a folyamat valahol megakad a Horvátország belépése elötti és utáni (EU-28 és az EU-27 állapota) között, és a brit tagsági viszony valamilyen, eddig ismeretlen részleges vagy csupán de facto tagsági állapottá alakul át. Az utóbbi azt jelentheti, hogy az Egyesült Királyság nem vesz részt a közös döntéshozatal felső szintjeinek müködésében (de az alsó, szakértői szinteken továbbra is képviselteti magát), a tagsággal járó egyéb jogok jó részét azonban továbbra is megtarthatja.

A macskamodellre építő elemzésünk három részből áll. Először a brexit különféle változatainak politikai feltételeit vizsgáljuk. Ezt a kereskedelempolitikai kapcsolatok lehetőségeinek áttekintése követi, kiemelve a szabadkereskedelem fenntartásának elképzelhetö kereteit. Végül a stratégiai opciók számbavétele következik.

\section{A brexit és a politika}

A 2016. június 23-i brit népszavazás eredménye nem teremtett jogi kötelezettséget. Az EU-szerződés 50. cikkében kifejtett kilépési mechanizmus nem lépett müködésbe a népszavazás következtében (Oulds [2015] 66. o.). A kilépésre készülő tagállamnak (értelemszerúen a kormányának) kell ugyanis bejelentenie a mechanizmus

\footnotetext{
${ }^{1}$ Itt szándékos a homályos fogalmazás.
} 
megindítását, $\mathrm{s}$ a folyamatnak ettől kezdve két éven belül kell lezárulnia. Ha ez alatt az idő alatt nem születik megállapodás a folyamat és a végeredmény összes részletéről, akkor a tagsági viszony magától megszünik. A kétéves időszakot csak az összes tagállam egyetértésével lehet meghosszabbítani.

A kilépés folyamatát nehezítheti és lassíthatja, hogy a kiválást a kilépő tagállam és az EU között megkötendő nemzetközi egyezményben kell rögzíteni. Ezt az egyezményt azonban minden tagállamnak külön-külön ratifikálnia kell ahhoz, hogy érvénybe is lépjen (Łazowski [2016] 2. o.). Amíg ez nem történik meg, addig a kiválásra készülő ország macskaszerü állapotban marad: de jure még tagállam, de facto azonban már nem tekintik annak a nemzetközi befektetők, a multinacionális vállalatok, sőt - persze legtöbbször ki nem mondva - a külföldi kormányok sem.

A közvéleményben elterjedt, hogy a brit választópolgárok kilépésre voksoló többségének jelentős része valójában nem kiválást akart, hanem csak erős figyelmeztetést szeretett volna küldeni Brüsszelnek. ${ }^{2}$ Erröl rendelkezésre áll egy érdekes felmérési eredmény. E szerint 2004 és 2016 között az EU elfogadottsága 54-ről 44 százalékra csökkent az Egyesült Királyságban, 83-ról 72 százalékra Lengyelországban, 80-ról 47 százalékra Spanyolországban, 78-ról 58 százalékra Olaszországban, 69-ről 38 százalékra Franciaországban és 58-ról 50 százalékra Németországban, illetve 2012 és 2016 között 37-ről 27 százalékra Görögországban (Stokes [2016] 3. o.).

Persze az ilyen felmérési eredményeket csak igen óvatosan szabad értelmezni, mégpedig legalább három okból:

1. az elégedetlenség nem teljesen, hanem csak ismeretlen arányban jelent kilépési szándékot;

2. ezekben az eredményekben megjelenhet az ország vagy a saját család/környezet romló gazdasági helyzete miatti elégedetlenség;

3. az utóbbi években sok helyen szokássá vált, hogy a lakosság vagy a vállalkozók egyre több gondjukra az EU-tól várnak megoldást akkor is, ha erre gyakran nincs is jogi lehetőség.

A felmérési eredményeket azonban az említett korlátok között el lehet fogadni, legalábbis, ami alapvető gondolatukat illeti. A tagállamok jelentős részében kétségtelenül csökkent az EU-val kapcsolatos elégedettség, és ez alól nem volt kivétel az Egyesült Királyság sem. Érdekes lett volna megtudni, volt-e felmérés a többi tagállam lakosságának a brit tagsági viszony fenntartását illető véleményéről, ilyet azonban sajnos nem ismerünk.

Pedig a brexit ellen a kontinensen megfogalmazott számos szakmai érv mellett elsikkadtak azok a megfontolások, hogy a brit tagság fenntartása egyes esetekben éppen az integráció fejlesztésének kerékkötője lehet. Forgács Imre véleménye elgondolkodtató: a brexit - tegyük hozzá, ma még esetleges - megvalósulása növelheti

\footnotetext{
${ }^{2}$ Medvegyev Péter elegánsan alátámasztott véleménye szerint a népszavazás előtti brit közvélemény-kutatások eredményéből valójában nem következett az akkor még többséginek hitt álláspont, a brexit ellenzése, mégpedig a szándékosan alacsony elemszám miatt. „Mivel a gazdasági szereplők igen tartottak a kilépéstől, egy problémás közvélemény-kutatásra építették a várakozásaikat és számításokat." (Medvegyev [2016] 1053. o.)
} 
az Európának makrogazdasági szempontból számos előnyt ígérő költségvetési unió esélyeit (Forgács [2016]).

Az Egyesült Királyság politikusai és szakértői sokszor kifejezték a mélyebb integrációtól való viszolygásukat, illetve azt az igényüket, hogy országuk ne tegyen meg a mélyebb integrációt elősegítő lépéseket (ennek két példája az euróövezetből és a schengeni zónából való kimaradás). A 2016-os népszavazáson a polgárainak többsége is ennek az álláspontnak a szellemében, pontosabban azon tovább is lépve voksolt.

Talán nem profán túlzás, ha Theresa Mayt „brexit-miniszterelnöknek” nevezzük magas pozícióját a népszavazás eredményeként kapta. Kilépési stratégiája világos és többszöri nyilatkozata („Brexit is Brexit!”) szerint visszavonhatatlan.

E felkiáltás első jelentése mindenképpen az, hogy a miniszterelnök aláveti magát a közvetlen demokráciának (ez persze más olvasatban a közvetett, azaz parlamenti demokrácia fontosságának relativizálását jelenti): a népszavazás eredménye a választóközösség akaratát fejezi ki, amely politikailag akkor is mérvadó, ha jogi érvényességét esetleg aggályok övezik. Theresa May nemegyszer hangsúlyozta is, hogy a brexitet elfogadó döntését nem kívánja a parlament elé vinni. ${ }^{3}$ Ez pedig egy olyan országban történik, amelynek történelme a törvényhozói hatalom igen erös parlamenti koncentrációját mutatja. Az Egyesült Királyságban eddig mindössze háromszor volt népszavazás, az első (1975) és az utolsó (2016) egyaránt az ország európai integrációban való részvételéről szólt.

A brexit nem feltétlenül kap majd többséget a brit parlamentben (a felsőházban különösen nem), de a fö kérdés nem is ez, hanem a brit kormány parlamentet megkerülni kívánó stratégiájának a sikeresélye. Kérdéses ugyanis, hogy a brit felsőbírósági rendszer (a másod-, illetve esetleg a harmadfok) hajlandó-e elfogadni a közvetlen demokrácia elsőbbségét a parlamenti demokráciával szemben.

Furcsa helyzet alakulhat ki. A brit választók közössége állást foglalt a brexit mellett, az EU elvben hajlandó tárgyalni erről, de a brit kormány 2017 elején Brüsszelnek benyújtandó (benyújtott) kiválási kérelme jogilag ingatag lábakon állhat. A közvetlen és a parlamenti demokrácia közötti konfliktus egyelöre nem dől el, a brexit - hogy képzavarral éljünk - a rajtvonalon áll, de lehet, hogy sokáig el sem mozdul onnan. A startpisztoly akár évekig nem dördül el ebben a különleges, egyszemélyes futóversenyben. Íme, a macskamodell sajátos 21 . századi változata.

Az EU oldaláról nézve mindez erősen másként látszik. Ott a brexit megvalósulása korántsem csupán rövid távú gazdasági következményekkel fenyeget, hanem mindenekelött a következővel.

Tegyük fel, hogy a brexit jogi értelemben teljes mértékben megvalósul, és az Egyesült Királyság kedvező pozícióban, az érdekeinek megfelelő kereskedelempolitikai, tőke- és munkapiaci szabályok elfogadásával zárja le a folyamatot. Ekkor olyan helyzet jöhet létre, amelyben az euroszkepticizmusra hajla mosabb országok még erősebb késztetést érezhetnek például a Nedxit, Cyxit, Grexit, Czexit vagy egyéb kilépés iránt. Azaz akár egyfajta hólabdaeffektus is fenyegethet. Ne feledjük: a brit

\footnotetext{
${ }^{3}$ S fellebbezni kíván a londoni törvényszék 2016. november eleji döntése ellen, amely kötelezi a kormányt a brexit kérdésének parlament elé terjesztésére.
} 
brexitről szóló népszavazás előtt nem folyt komoly vita az akkor még esetleges kiválás részletes gazdasági, jogi és politikai feltételeiről, és ez nem várható a jövőbeli hasonló kezdeményezések esetében sem! Lényegük ugyanis szintén sokkal inkább politikai, mintsem szakmai jellegü volna.

A brexit másik politikai következménye az Európai Parlament struktúrájának jelentős és első látásra paradox átrendeződése lenne. Azok az országok járnának jól, amelyek többségi - vagy kormányzati - integrációfejlesztési stratégiája szemben áll a brit népszavazáson győztes állásponttal. E várható átalakulás megítéléséhez hasznos tudni, hogy a brit Konzervatív Párt euroszkeptikus csoportjait azzal az érvvel nyerték meg a brexit melletti állásfoglalásra, hogy az Egyesült Királyság kilépés utáni európai helyzetét „a szabadkereskedelem és a kormányközi együttműködés” határozza meg (Liddle [2015] 19. o.). Erre azonban senkitöl sem hangzott el komoly ígéret.

A számítások szerint az úgynevezett liberális blokk (ma még az Egyesült Királyság, valamint az északi tagországok, Hollandia, Csehország, Szlovénia, Szlovákia, Írország, a balti államok és sok esetben Németország), azaz a megengedőbb uniós szabályozást pártoló csoport nem tudná kollektív vétójával ${ }^{4}$ megakadályozni a - blokkoló - többség által szükségesnek tartott jogszabályok megalkotását, mert együttes arányuk 41-röl 33 százalékra esne a brit kiválás után (Irwin [2015] 15. o.). A brit kilépés nemcsak alaposan meggyengítené az ország uniós szövetségeseinek táborát, hanem de facto meg is bénítaná ezt a tábort.

Akkor pedig, ha a brexit után a britek valamilyen társult viszonyt szeretnének fenntartani az EU-val, tudomásul kell venniük, hogy a szabályok kidolgozóiból (rule maker) a szabályok passzív követőivé (rule taker) kell majd válniuk (Irwin [2015] 14. o.; McFadden-Tarrant [2015]). Az ilyen változást általában nemcsak az egyéneknek, hanem a politikai közösségeknek is nehéz elfogadniuk.

A további deregulációs törekvések európai támogatói jelentős szövetségest veszítenek el a brexit következtében (Kierzenkowski és szerzötársai [2016]), amivel paradox helyzet áll elő: az Egyesült Királyság a dereguláció egyik legaktívabb híve volt az EU-ban, kilépése viszont éppen a több szabályozást igénylő oldalt erősíti.

Egyelőre nem lehet számolni azzal, hogy az EU szoros intézményi kapcsolatra törekszik majd a brexit utáni Egyesült Királysággal (McFadden-Tarrant [2015] 61. o.). Nagyon valószínü, hogy a „kimazsolázás” (cherry-picking) lehetséges brit stratégiája ellen már a kiválási folyamat elején igen határozottan fog fellépni az EU. A „kimazsolázás” fogalma itt azt jelenti, hogy a britek ott törekednének szorosabb kapcsolatra (például az árukereskedelemben vagy a tőkepiaci szabályozásban), ahol ez előnyükre válna, és ott komolyabb visszalépésre az integrációs vívmányoktól (például a munkaerö áramlását vagy a közös költségvetésbe való befizetéseket illetően), ahol ök éppen ezt szeretnék.

A „kimazsolázás” stratégiája brit szempontból több területen akkor is kockázatos lenne, ha az EU nem is állna ellen ennek a stratégiának. Vannak ugyanis olyan területek, ahol az integráció jövőjével kapcsolatos brit érdekek „kétcsúcsú preferenciák” szerint alakulnak. Ilyen például a mezőgazdaság.

\footnotetext{
${ }^{4}$ Az úgynevezett blokkoló kisebbség küszöbértéke 35 százalék.
} 
A britek elutasítják az uniós mezőgazdaság jelenlegi működési modelljét a centralizált szabályozás és a rendszer magas költségei miatt. Azt azonban kevésbé hangoztatják, hogy a brit gazdák jövedelmeinek jelentős része (egyes források szerint 60 százaléka) uniós támogatásokból származik (McFadden-Tarrant [2015] 30. o.). A brexit után ezek elvesznének, és a brit kormánynak pótolnia kellene őket, ami lényegesen csökkentené a brit költségvetési pozíció kiválástól várt javulását. ${ }^{5} \mathrm{~A}$ brit mezőgazdaság pozícióit azzal is ronthatná a brexit, hogy a brit mezőgazdasági export háromnegyedét az EU veszi fel, mintegy 15 milliárd dollár értékben (Mansfield [2015] 12. o.), és e kivitel egy részének más piacokat kellene találni. Az EU agrárpiacát ugyanis magas, átlagosan 13,2 százalékos vámok védik (Irwin [2015] 22. o.), miközben a brit agrárexport versenyképességét több ágazatban is gyengíti a farmergazdaságok csekély átlagos mérete (McFadden-Tarrant [2015] 30. o.).

A kétcsúcsú preferenciák problémája a brit gazdaság más kulcságazataiban is nagyban megnehezítheti a brexit utáni piaci helyzethez való alkalmazkodást. Különösen ott, ahol magas az EU-ba irányuló export aránya a kibocsátásban. Vegyük példának az autóipart! Ez az iparág az 1980-as években újult meg az Egyesült Királyságban, miután Margaret Thatcher következetes iparpolitikája véget vetett a versenyképtelen iparágakat életben tartó állami támogatásoknak (lásd Edwardes [1985]). ${ }^{6}$

A brit autóipari megújulást nagyrészt Európán kívüli székhelyủ multinacionális vállalatok finanszírozták (elsősorban a Toyota, a Nissan és a Honda, s részben még a GM és a Ford). Ezek a cégek új gépkocsigyárakat építettek, illetve a régieket bővítették az Egyesült Királyságban, főleg az EU-ba irányuló export bővítésének szándékával. A brexit jelentősen ronthatja ezeknek a kapacitásoknak az uniós piaci versenyképességét, hacsak a brit kormány nem tesz számottevő - például munkaerőpiaci - engedményeket az uniós piachoz való vámmentes bejutás megtartásáért. Az ilyen engedmények azonban magát a brexitet is részben értelmetlenné tennék.

A brit telephelyű autógyártók ugyanakkor gyakran panaszkodtak a túl szigorú uniós munkajogi, környezetvédelmi vagy közbeszerzési szabályok miatt - azaz második preferenciacsúcsként kifejezték az EU-val szembeni ellenérzéseiket is. Érdekeltségi pozíciójuk tehát ellentmondásos: olyan piac résztvevői szeretnének maradni, amelynek szabályait nem fogadják el szívesen.

A brexit utáni brit-EU együttmüködési rendszer jogi alapjai még nem rajzolódtak ki, és ezek kidolgozásánál ugyancsak megjelenhet a brit fél „kimazsolázó” stratégiája. A munkaerő és a tőke szabad áramlása a négy alapvető uniós „szabadság” közé tartozik. A brexit ideológusai és propagandistái rendszeresen hangoztatták, hogy következetesen elutasítják a szabad munkaerö-áramlást a Brit-szigetek Londonból irányított részei és a kontinens között. Ezt az álláspontjukat elsősorban a bevándorlási veszéllyel indokolták, amelyet a brit foglalkoztatási problémák fö okának tartottak (Blockmans-Weiss [2016]).

\footnotetext{
${ }^{5}$ Valójában analóg folyamat játszódnék le azzal, ami az 1840-es években a brit gabonavámok eltörlése következtében történt: a külgazdasági szabályozás megváltozása a mezőgazdaság kárára rendezte át a belföldi jövedelmi viszonyokat.

${ }^{6}$ A legtöbb hagyományos brit autómárka vagy autógyár (a többi között az Austin, a Morris, a Leyland, a Hillman, a Wolseley vagy a Riley) nem érte meg még a kilencvenes évek elejét sem.
} 
Ezek a véleményvezérek ugyanakkor gyakran próbáltak integrációpártinak is mutatkozni. Kifejezték szándékukat, hogy az Egyesült Királyság a jövőben is tartsa fenn az EU-val az áruk és a tőke, valamint a pénzügyi szolgáltatások szabad áramlását (Liddle [2015] 19. o.). Éppen ez a „kimazsolázás” lényege: csak a brit szempontból előnyösnek látszó területeken fenntartani az Unióhoz füződő könnyített kapcsolatokat.

A „kimazsolázás” ötletét aligha nevezhetnénk stratégiának, de tény, hogy a Bank of England éppen azért foglalt el mindvégig következetesen brexitellenes stratégiai álláspontot, mert erős intézményi érdeke füződött a tőkeáramlás szabadságának fenntartásához (Blockmans-Weiss [2016]). Elöre tudta ugyanis, hogy az EU nem engedi majd meg ennek az integrációs területnek a külön kezelését.

A brexittámogatók információs hadviselésének lényeges eleme volt, hogy a népszavazást két, valójában mesterségesen konstruált véglet közötti választásként próbálták beállítani. Ezek egyikét, a rokonszenvesnek tekintett változatot a bevándorlási politika fölötti ellenőrzés ,visszavételeként” ábrázolták úgy, hogy az ország közben az egységes európai piac része maradna - ami természetesen jogi képtelenség. Másik, kedvezőtlen végletként pedig az Egyesült Királyság feloldódását rajzolták fel egy úgynevezett európai szuperállamban. Azt azonban nem jelezték, hogy ez a „szuperállam” fogalom nem létezik egyetlen komolyan vehető európai politikai vagy politológiai mühelyben sem.

A brexittábor mintha nem vett volna tudomást az együttmüködés két véglet közötti számos lehetséges változatáról. Ezek némelyike például egyéb - esetleg nem is munkaerőpiaci - kompromisszumokat tartalmazhatna cserében a szabad tőkeáramlás fenntartásáért, és így nagyban megfelelne a brit érdekeknek.

A liberális tőkeáramlási szabályozás megtartása az EU és az Egyesült Királyság között megfelelne a londoni City érdekeinek, ${ }^{7}$ amely maga is sokszor kiállt az EU-n belüli reformok mellett (TheCityUK [2015]). A bürokratikus uniós munkaerőpiaci szabályozás korábbi brit igényeknek megfelelő lazítása az EU-ba irányuló uniós munkaerő-áramlás lehetőségének fenntartása mellett szintén a kompromisszumos csomag része lehetne. A munkaerő implicit költségei nagyban megnőttek a túlzott beavatkozási szigor miatt, ${ }^{8}$ amit csak részben ellensúlyozott a megengedő brit munkaerö-beáramlási szabályrendszer. ${ }^{9}$ Az így kapott viszonylagos kedvezményekért a brit fél például a brexit után nagyobb befizetéseket vállalhatna az uniós költségvetésbe a norvég példa szerint. Mindez azonban egyelöre csak fikció vagy kívánalom.

Az ilyen jellegü kompromisszumok azonban Brüsszelből nézve aligha elfogadhatók. Az EU várható brexittárgyalási stratégiája ugyanis aligha tartalmaz majd olyan elemeket, amelyek esetleg más országok kilépését elősegítö ösztönzőkként érthetők.

\footnotetext{
${ }^{7}$ A brexit lehetséges következményeivel foglalkozó brit publikációk közül már az egyik legelső is a City aggodalmaival foglalkozott (Springford-Whyte [2014], lásd még Lannoo [2016]).

${ }^{8}$ Példa erre a 3,5 tonnásnál nagyobb teherautók vezetésére vonatkozó uniós szabályozás. Az elöírások napi, heti és kétheti bontásban adják meg a vezetés órában mért maximális időtartamát. Szabályozzák továbbá, hogy naponta és hetente legalább mennyi időt kell megszakítás nélküli pihenéssel tölteni úgy, hogy közben betartsák a 6, illetve 11 nap vezetés után kötelező pihenési időt is (Mansfield [2015] 25. o.).

${ }^{9}$ A brit gazdaság bizonyos alacsony hozzáadott értékű és bérszintű ágazatait akár összeomlás is fenyegetheti, ha eltűnik onnan a kelet-európai munkaerő (lásd McFadden-Tarrant [2015] 29. o.).
} 
A brit oldalon elképzelhető, hogy lassítják a kilépési tárgyalásokat azért, hogy tisztábban lássák a brexitcsomag különböző elemeinek belföldi fogadtatását. Az uniós oldal pedig nem feltétlenül sürgetné brit partnerét, mert abban bízhatna, hogy a brexit végül csak a vártnál kevesebb területen valósul meg.

\section{Kereskedelempolitika - egyszerre kint és bent?}

A legtöbb brexittámogató nem gondolta végig az EU és az Egyesült Királyság közötti kereskedelmi kapcsolatok jövőjét, illetve nem volt erröl kiérlelt elképzelése (Emerson [2016a] 2. o.). Ettől függetlenül lehetséges, de nem biztos, hogy a kereskedelempolitikai kérdések majd előkelő helyen szerepelnek a brexittárgyalások napirendjén. A brexitre vonatkozó népszavazást előkészítő kampányban a kilépés szószólói valószínűleg magától értetődőnek vélték, hogy a két fél között fennmarad az uniós tagok közötti szabadkereskedelem. Brit szempontból ez optimista, de érthető várakozás volt: az uniós szabadkereskedelem a kereskedelemteremtö hatás miatt jelentős hasznot hozott a szigetország feldolgozóiparának (Booth és szerzötársai [2015]).

Könnyen lehet azonban, hogy a brexitfolyamat végén az Egyesült Királyság és az EU között a WTO vámszabályai lesznek érvényesek. A WTO tagjai közötti legnagyobb kedvezményes (MFN) vámok súlyozott átlaga valamivel 3 százalék alatt van, az EU külső vámtarifájának súlyozott átlaga pedig a számos preferenciális külső vám miatt alig 1 százalék (Booth és szerzőtársai [2015] 27. o.). Ezek a vámszintek gyakorlatilag közel állnak a teljes szabadkereskedelemre jellemző értékekhez - csakhogy a forgalmat a vámok mellett más kereskedelempolitikai eszközök is csökkenthetik, illetve szabályozhatják.

Az EU és az Egyesült Királyság közötti szabadkereskedelem megszüntetése több brit iparág számára is jelentős versenyképességi hátrányt okozna a következők miatt:

1. A WTO-n belüli átlagos vámszint valóban nagyon alacsony lett az elmúlt években. Az átlag azonban nem mutatja az úgynevezett vámcsúcsokat (tariff peaks), amelyek az érzékenynek tekintett termékek uniós piacát védik (például 10 százalékos vámtarifa a személygépkocsikra, 5 százalékos az alkatrészeikre - McFaddenTarrant [2015] 20. o.).

2. Az átlagos vámszintek olyan alacsonyak, hogy a WTO liberalizációs stratégiájának már a kereskedelem nem vám jellegü eszközeinek (Red Tape Barriers, RTB) ${ }^{10}$ felszámolása áll a középpontjában. Az EU és az Egyesült Királyság közötti forgalomban a brexit után könnyen megjelenhetnek ezek az eszközök.

Ez persze attól is függ, hogy a brexit után milyen forgatókönyv vagy minta szerint alakulnak az EU és az Egyesült Királyság közötti kereskedelmi kapcsolatok

\footnotetext{
${ }^{10}$ Red Tape Barriers - a kereskedelem nem vám jellegű („paratarifális”) korlátozó eszközei. Ilyenek lehetnek például a származási szabályok, a szabványok, az egészségügyi, növényvédelmi, állategészségügyi, csomagolási, környezetvédelmi és egyéb, sokszor látszólag csak technikai jellegű elöírások, amelyek az importot befolyásolják.
} 
(Hulsman [2015]; Mansfield [2015]; Emerson [2016b]; de Vries-Hoffmann [2016]; McFadden-Tarrant [2015]). Négy lehetséges modellnek már van mintája az EU gyakorlatában, ezeket norvég, svájci, török és EFTA-modellnek nevezik, az ötödik pedig nem preferenciális vámokkal szabályozott kapcsolatként képzelhető el a WTO rendszerében - ez akkor érvényesülne, ha egyik preferenciális modellben sem sikerül megállapodni. Az utoljára említett megoldás szerint a brit külkereskedelem könynyen átirányulhat Észak-Amerika és a Nemzetközösség országai felé, de ezt az opciót általában nem tekintik túl valószínűnek.

A négy, valamilyen értelemben kooperatív kereskedelempolitikai változat közül a norvég áll a legközelebb ahhoz, mintha az Egyesült Királyság EU-tagsága fennmaradna a brexit után is. Más megközelítésben ez a brexit „visszafogott” változata volna. Norvégia az Európai Gazdasági Térség tagja, és korlátozások nélkül hozzáfér az egységes európai piachoz. Igazodnia kell az EU egységes piaci szabályaihoz, és alkalmaznia kell rendeleteit, viszont van is bizonyos befolyása azok alakítására, különösen a környezetvédelem területén (Oulds [2015] 73. o.; McFadden-Tarrant [2015] 7. o.).

Norvégia korlátlan egységes piaci hozzáférésének ára az is, hogy részt vállal az EU kiadásaiból. Igaz, nem közvetlenül az uniós költségvetés befizetője, hanem a szociális és a kohéziós alapokhoz járul hozzá. A magyarországi „Norvég Alap” ennek a hozzájárulásnak az egyik megjelenési formája.

A brit euroszkeptikusok - azaz részben, de nem teljesen a brexittámogatók - erősen ellene vannak ennek az együttmüködési modellnek. A norvégok uniós befizetései ugyanis meglepően magasak. Egy före számított szintjük 2011-ben 80 százaléka volt az Egyesült Királyság egy före jutó uniós költségvetési befizetéseinek (McFadden-Tarrant [2015] 12. o.). Egy másik forrásból származó adat közvetve megerősíti ezt a szinte megdöbbentő információt: ha az Egyesült Királyság brexit utáni nettó közös költségvetési hozzájárulását a norvég metodika alapján számítanák ki, akkor az csupán 9 százalékos csökkenést mutatna fejenként. Ha viszont a svájci módszer szerint számolnának, akkor a csökkenés már 55 százalékos lenne (Irwin [2015] 26. o.). Látni fogjuk, hogy a svájci modell viszont csak sokkal nehezebb hozzáférést biztosít az EU egységes belső piacához.

A norvég megoldás brexitpárti ellenzői a tömör „nem szólsz bele, de fizetsz” (no say, still pay) panaszban foglalják össze álláspontjukat (Emerson [2016b] 10. o.). Itt nem beszélhetünk egy mély gazdasági gondolat alaposabb kifejtéséről, de a brexittábor nem is használt sok gazdasági érvet a népszavazási kampányban (Łazowski [2016] 2. o.). A norvég megoldás valóban nem lenne a bennmaradás észszerü alternatívája, hiszen a britek úgy adnák fel uniós döntéshozatali szerepüket, hogy pénzügyi terheik közben nem is oly sokkal csökkennének.

A svájci modell sokkal bonyolultabb, mert szektoronkénti szabadkereskedelmi megállapodásokon alapul. Svájc tagja ugyan az EFTA-nak, de az Európai Gazdasági Térségnek már nem. Így az uniós szabályokat csak azokban a szektorokban alkalmazza, ahol a szabadkereskedelem fenntartása ezt szükségessé teszi (Irwin [2015] 6. o.). Az EU már a svájci kapcsolatban is érzékeli a „kimazsolázási” problémát, azaz azt, hogy a másik félnek olykor túl erös a befolyása a szabadkereskedelemre kijelölt 
szektorok kiválasztására. Így feltételezhető, hogy jövőbeli brit kapcsolataiban sem szorgalmazza majd a svájci megoldást.

Ezt az uniós aggodalmat jogi oldalról a „guillotine-záradék” testesíti meg. E szabály szerint az EU és Svájc közötti összes bilaterális kereskedelmi megállapodás egyetlen csomagba tartozik, azonos érvényességi idővel és lejárattal (McFadden-Tarrant [2015] 14. o.); tehát nincsenek ágazati kivételek. A svájci pozíció azért is gyengébb ebben a kapcsolatrendszerben, mint a norvég, mert informálisan sem kérdezik meg az őket érintő uniós szabályok átalakításáról. A svájci modell tehát most már valójában csak átmeneti, az EU ebben a formában nem ragaszkodik hozzá, de többé Svájcnak sem igazán előnyös. Aligha szolgálhat a brit-EU kapcsolatok mintájaként a brexit után, annál kevésbé, hogy az EU-álláspont is már a Svájchoz füződő kapcsolatok átalakítását szorgalmazza (Emerson [2016b] 13. o.).

Maradna akkor a török modell? Ennek alapja a vámunió (a nem feldolgozott agrártermékek kivételével), ami annyit jelent, hogy a partnerország az EU közös külső vámtarifáit alkalmazza, nem fizet be a közös költségvetésbe, és számos ágazatban szabad hozzáférése van az egységes belső piachoz. Ezzel szemben semmiféle hatása sincs az uniós belső piaci és külkereskedelmi szabályozásra, és csak részben, mégpedig éppen kedvezőtlenül vonatkoznak rá az EU külső preferenciális kereskedelmi egyezményei vagy szabadkereskedelmi megállapodásai (Irwin [2015] 6. o.). Ez annyit jelent, hogy a harmadik országokkal szemben alkalmaznia kell az EU preferenciális vámjait (ahol vannak ilyenek), de az ellentételezést külön-külön végig kell tárgyalnia ezekkel az országokkal (Emerson [2016b] 10. o.).

A török modellt 2016 júniusa óta természetesen a brexit elképzelhető követelményeihez viszonyítják. Egyes források a brexit „erős” változatának tekintik, amelyben a kereskedelmi liberalizáció az együttmüködés fö területe, az agrártermékek, a munkaerő, a tőke és a szolgáltatások szabad áramlásának a fenntartása nélkül (Mansfield [2015] 4. o.). Az EU-török kapcsolatok esetében érthető is lenne ez a relatív elzárkózás az EU „távoltartási” stratégiája miatt, a brit esetben azonban még a brexit után sem lennének hasonló, óvatosságra intő politikai motívumok.

A török modell esetleg elképzelhető volna egy „brit stílusú” extra változatban, amely magában foglalná a pénzügyi szolgáltatások liberalizációját is (Ernst and Young [2016] 5. o.). Ennek a változatnak az egyik gyenge pontja az volna, hogy a briteket továbbra is megfosztaná a teljes szabadkereskedelem előnyeitől, a másik pedig, hogy Brüsszel a szabad munkaerő-áramlás biztosítása nélkül tenne jelentős engedményeket. Mindezt figyelembe véve, a török modellt lényegére csupaszítva a norvég modell mindkét fél számára kedvezötlenebb alváltozata állna előttünk (Emerson [2016b] 16. o.). Komolyabb politikai támogatása egyik oldalon sem valószínü.

Az EFTA- (vagy szabadkereskedelmi társulási) modell számos részlete még homályos, de a „kimazsolázás” veszélye itt sem elhanyagolható. Átváltási kapcsolat lehet ugyanis az egyes területeken a valamelyik fél erős érdekeltsége miatt fenntartott szabadkereskedelem és a brit fél kereskedelempolitikai ügyekben igényelt jelentős döntési autonómiája között (Irwin [2015] 6. o.). Érthetőbben: ez a norvég modell olyan „klónja” volna, amelyben a brit fél csak akkor lenne érdekelt, 
ha magas szabadságfokkal „mazsolázhatna” a szabadkereskedelem fenntartására kijelölhető ágazatok között.

Az EFTA-modell éppen azért látszik bizonytalan tartalmúnak, mert többféle forgatókönyv szerint is megvalósulhatna. Általános formájában csak csekély politikai támogatásra számíthatna Brüsszelben. A brit szempontból várhatóan kedvező előnyhátrány mérlege miatt ugyanis hivatkozási alappá válhatna akkor, ha újabb tagállam kezdené fontolgatni a kilépést. Az EFTA-modell megvalósulása tehát kevésbé valószínü, $s$ ha mégis komolyan számításba vennék, tárgyalási folyamata aligha lenne rövidebb két évnél. Két éven túl pedig az összes tagállam jóváhagyása kellene a brexittárgyalások folytatásához.

A négy leggyakrabban említett kereskedelempolitikai opció egyike sem mutatja a kölcsönös előnyök olyan összhangját, a melynek alapján gyors megegyezés lenne elképzelhetö. Az ötödikként esetleg lehetséges megoldás a tárgyalások sikertelensége esetén állhatna elö. Ekkor a brexit után már nem lenne külön kereskedelempolitikai együttmüködés az EU és az Egyesült Királyság között, és a WTO - legnagyobb kedvezmény elvén (MFN) alapuló - általános szabályai szerint kereskednének egymással.

Ez a modell akkor nyerhetne gyakorlati jelentőséget, ha két év alatt valóban nem sikerülne megállapodni a brexit feltételeiről. A WTO-szabályok szerinti kereskedelem azonban akár a kontinens felé irányuló brit áruexport egyes szegmenseinek összeomlását is jelenthetné. Az EU piacára kerülő brit árukivitel több mint 35 százaléka olyan termékcsoportokból áll (mint a vegyi áruk, gépkocsik, ruházati cikkek, élelmiszer, ital és dohány), amelyek legnagyobb kedvezmény elve szerinti vámtarifája magas (Booth és szerzőtársai [2015] 17. o.).

Ez a modell tehát inkább csak a brit külkereskedelem viszonylati megoszlásának átalakulásával lehetne müködőképes, ami elsősorban az Észak-Amerika és a nemzetközösségi országok felé való reorientációt jelentheti. A nagyobb szállítási költségek és távolságok miatt azonban így is a jelentősebb, föleg anyagigényes termékcsoportok szerepének csökkenése lenne várható.

Ilyen forgalomátrendeződésre már volt példa az elmúlt években, ${ }^{11}$ mégpedig a brit kivitel mély strukturális átalakulása mellett. A szolgáltatások kivitele teret nyert, a hagyományos értelemben vett áruexport viszont visszaszorult. 2012-es adatok szerint az Egyesült Királyság EU irányú áruforgalmában több mint 100 milliárd dolláros deficit képződött, a szolgáltatások kereskedelmében viszont ugyanebben az irányban mintegy 80 milliárd dolláros többlet keletkezett (McFadden-Tarrant [2015] 23. o.).

A hagyományos szolgáltatások (szálloda, étterem, színház, egészségügy, helyi közlekedés, kertészet, házvezetés, fodrászat és még sok más) általában nagyrészt csak a belföldi piacot látják el, ezért „importversenytől megkímélt” (sheltered) szektoroknak vagy szolgáltatásoknak is nevezik öket. A brit külpiaci versenyképesség azonban

${ }^{11} 2002$ és 2012 között az EU részesedése 55-ről 45 százalékra csökkent a brit külkereskedelemben (Mansfield [2015] 9. o.). 2015-ben az EU-28 országok közül csak Máltán volt alacsonyabb az EU-n belüli kereskedelem részaránya, mint az Egyesült Királyságban. 
2000 után éppen a nem hagyományos szolgáltatásokban bontakozott ki, ahol nem, vagy csak alig van szükség a fizikai áruszállítással történő teljesítésre. Idetartoznak például a jogi, pénzügyi, távközlési, a technológiaexporttal összefüggő, a tanácsadási, légi vagy tengeri szállítási és általában véve az üzleti szolgáltatások.

Ez a szerkezeti átalakulás az esetek többségében nem szektorok között zajlik le, hanem vállalatokon belül. ${ }^{12} \mathrm{~A}$ világ számos vezető iparvállalata áruexportőrből szolgáltató céggé alakul át. A repülőgép-hajtómüvek gyártói (a GE, a Pratt \& Whitney vagy a Rolls-Royce) például egyre inkább komplex repülőgép-ipari technológiai szolgáltatásokat (bennük például karbantartást) adnak el az egyszerü turbinaexport helyett. Gyógyszeripari cégek terápiás csomagok részeként értékesítik tablettáikat vagy injekcióikat, és sok építőipari cég kínál komplex ingatlanfejlesztést, amelynek csak egy része maga az építkezés.

Elvben elképzelhetö lehet tehát a brexit nyomán egy olyan új brit külgazdasági stratégia, amely kettős fordulaton alapulna. Ezek egyik eleme lehetne az áruexport további visszaszorulása a szolgáltatások kivitelével szemben, vele szoros összefüggésben a másik pedig a viszonylati átrendeződés az EU-kapcsolatok kárára. Egyes források már felvetették egy ilyen kettős fordulat lehetőségét, de mélyebb elemzésekkel még nem rendelkezünk (Hulsman [2015], Buckle-Hewish [2015], Irwin [2015]).

A brexit után elképzelhető kereskedelempolitikai forgatókönyvek kidolgozottságának hiánya összefügg a brexit stratégiai megalapozatlanságával. A kampány nagyrészt érzelmi-indulati alapon folyt, és feltételezhető, hogy szervezői azért nem foglalkoztak stratégiai kérdésekkel, mert úgy gondolták, hogy a közönségük nem is lenne kíváncsi rájuk. „A brexit melletti érvek alacsony szakmai színvonala” („the low level of professionalism of pro-Brexit arguments", Emerson [2016a]) a kereskedelempolitikára különösen érvényes megállapítás.

Az Egyesült Királyság az EU és az Egyesült Államok közötti szabadkereskedelmi egyezmény (TTIP) egyik fő szószólója volt az EU-n belül (Irwin [2015] 23. o.), és a brit kormányzatnak a brexitről szóló népszavazás előtt elsősorban a transzatlanti szabadkereskedelmi megállapodással kapcsolatban volt kereskedelempolitikai jövőképe. A TTIP jövője azonban még brexit nélkül is igen kérdéses lenne, hiánya és a brexit együtt pedig új, Európán túlra mutató brit kereskedelempolitikai stratégia kidolgozását követelné meg. Ehhez azonban sem erős belpolitikai támogatás, sem elég idő nem áll rendelkezésre a 2016 végi jelek szerint.

Ez ismét olyan helyzet, amelyből nem látszik gyors kiút - a macska problémája megint velünk van. A brexit utáni kereskedelempolitikai opciók áttekintése megmutatta, hogy egyáltalán nem világos, mi is lehetne a következö lépés az EU szabadkereskedelmi rendszeréből (régi kifejezéssel a közös piacról) való brit távozás után. A brit kormány 2017 tavaszára várható (pontosabban ígért) brexitbejelentése idézi elő azt az állapotot, amikor a macska kívülről nem látható a zárt dobozban. Kereskedelempolitikai szempontból több mint kérdéses, hogy a bejelentéstől számított két éven belül valóban ki lehet-e nyitni majd a dobozt.

\footnotetext{
${ }^{12}$ Lásd ehhez az ágazatközi (inter) és az ágazaton belüli (intra) kereskedelem problémáját (Krugman és szerzőtársai [2015]).
} 


\section{Hogyan tovább?}

A brexit tényleges eshetősége még mindig valahol - s talán jóval - a 100 százalékos valószínüség alatt van. A nyitott kérdések sorozata egyelöre hosszú. Kezdve azzal, hogy az eddigi brit politikai aktusok és nyilatkozatok mennyire tekinthetők a kilépés érvényes jogi alapjának, folytatva ott, hogy mi volna az elképzelhető, integrációt fenntartó vagy felrúgó kereskedelempolitikai forgatókönyvek optimális keveréke, egészen addig, hogy a különböző brit politikai, gazdasági és társadalmi érdekcsoportok (az Olson-féle értelemben mondhatjuk: „elosztási koalíciók”) végül milyen megoldásban tudnának majd megállapodni.

Persze az sem biztos, hogy lesz egyáltalán ilyen megállapodás. Képzeljük el az Egyesült Királyság miniszterelnökét, mondjuk, 2018 végén, aki felismeri, hogy sokkal több politikai feszültséget okozhat az országban a brexitmegállapodás részletesen kidolgozott csomagja, mint ha még tovább megpróbálnának fenntartani egy „brexit általában: igen, konkrét brexitprogram: nem" jellegü átmeneti állapotot.

A brit politikai vezető 2018-ra elképzelt álláspontja előtt, már 2017 elejétől magát a tárgyalási folyamatot is ez a kettősség jellemezheti. A brexit kifejezést sem értik egyformán az Egyesült Királyságban. Van, aki lezárt tényként, más viszont folyamatként, ismét más jövőbeli lehetőségként beszél róla. Az idősíkok ilyen keveredése pedig megint felidézi a brexit és a Schrödinger-féle macskamodell közötti párhuzamot. Mégpedig azt, hogy a brexit most és még egy darabig az úgynevezett harmadik állapotban van, illetve lesz.

Az Egyesült Királyság az EU tagjaként egy gazdasági, s részben egy jogi integrációs szervezet tagja, amelyben jelentős költségeket kell viselnie számottevő haszon fejében. A brexittábor (pontosabban: nyomásgyakorló csoport) úgy tett a népszavazás elött, mintha pontosan ismerné az európai integráció brit szempontból tekintett előny-hátrány mérlegét, s folyton hangoztatta, hogy ez a mérleg az ország számára kedvezőtlen. 2016 első felében nemcsak ezt a mérleget nem tudták pontosan bemutatni, hanem adósak maradtak „a brexit hihető és könnyen érthetö forgatókönyvével is" (Weiss-Blockmans [2016] 14. o.).

A jóval kevésbé agresszív és sokkal halkabb brexitellenes tábor viszont nem használta ki esélyét, és nem mutatta be a brit szempontból szerinte kedvezö integrációs előny-hátrány mérleget. Egyes képviselői azért megszólaltak, de ők inkább szakmai fejtegetésekbe bocsátkoztak annak bemutatására, hogy ilyen mérleget mérési és összehasonlítási problémák miatt nem is lehetne szakszerüen elkészíteni.

Emellett pedig - visszafogott és szakszerủ stílusban, teli finom bennfentes utalásokkal - kiemeltek egyes területeket, ahol szerintük talán lehet értelme a hasznok és a költségek szembeállításának. Például: „További bevándorlási, müködőtőke-mozgási és szabályozási hatások várhatók. Nehezebben számszerüsíthető módon, de a brexit valószínüleg a jövedelmek csökkenését okozza majd az említett csatornákon keresztül." (Ottaviano és szerzőtársai [2014] 1. o.)

Hasonló állítás: „a kompetenciák mérlege a brit érdekeket szolgálta az áruk és a szellemi tulajdonjogok szabad mozgása terén” (Emerson [2016b] 51. o.). Vagy: „a brexit nemcsak brit szempontból volna rossz, hanem összességében az EU számára 
is. Mindkét fél éveket vesztegethet el egy új kapcsolatrendszer letárgyalásával. Olyan korszakban, amikor nyomás alatt van a második világháború utáni nemzetközi rendszer, Európa társadalmait pedig növekvő mértékben fenyegeti a protekcionizmus, mindennél nyilvánvalóbb, hogy az EU-nak minden korábbinál alkalmasabbnak kell lennie a nagy globális kihívásokkal szembeni határozott fellépése." (Blockmans-Emerson [2016] 17. o.)

A brexitről 2016 októberében rendelkezésre álló angol nyelvü irodalom egy további elgondolkodtató tanulsággal is szolgál. Ez a tanulság teljesen egybecseng azokkal a forrásokkal, amelyektöl fentebb idéztünk a brexittábor némileg korlátozott szellemi és kutatási kapacitását illetően. 31 olyan angol nyelvü, általában tudományos, de nem feltétlenül elméleti igényü publikációt tekintettünk át, amely mind 2014 és 2016 között keletkezett a brexitről.

A feldolgozott 31 közleményből 26-ot teljes mértékben a brexitet nyíltan elutasító állásfoglalásnak tekinthetünk. További öt tanulmány mérsékelt, többé-kevésbé semleges vagy agnosztikus álláspontot képvisel a brexitröl úgy, hogy közülük talán kettő felveti a brexit hasznának lehetőségét egyes szükebb brit szektorok szempontjából. A nyilván korlátozott minta egyetlen eleme sem fogalmaz meg határozott brexitpárti véleményt az európai integráció egyetlen fontosabb területére vonatkozóan sem.

Egyfajta patthelyzetről beszélhetünk tehát annyiban, hogy a brit és a nemzetközi közgazdászszakmai közösség megpróbálta felhívni a figyelmet a brexit veszélyeire és súlyosan tisztázatlan pontjaira, a brit választók megnyilvánuló (tudniillik a népszavazáson részt vevők arányában számított) többsége azonban nem vette figyelembe ezeket a vészjelzéseket, vagy nem is tudott róluk. A tömegpszichológia erősebbnek bizonyult a tudományos gondolkodásnál.

2016 őszén erös a benyomás, hogy a brexittábor kezdeti eufóriája (tegyük hozzá: a tábor egy részével együtt) jórészt elpárolgott. A brit politikai elit egy része az elhagyott csatamezőn maradt azzal a feladattal, hogy teljesítse a nép talán már csak múlt időben érvényes többségi kívánságát. Ez a (kormányzati) elitcsoport pontosan tudja, milyen veszélyek fenyegetik küldetésének teljesítése során, miközben a brexitellenes tábor továbbra is egyben van, bár a jelek szerint nem készül a folyamat blokkolására. A mélyen és nem csak formálisan demokratikus brit társadalomban komolyan nem jöhet szóba a brexit visszafordítása, véghez vitele viszont számottevő gazdasági veszteségekkel fenyeget alapvetö fontosságú iparágakban.

Az ennek a játszmának a két intézményi főszereplöje előtt álló stratégiai döntési opciók egyáltalán nem összehasonlíthatók. Az EU, legalábbis egyelőre, passzivitásra van kárhoztatva: meg kell várnia a britek valóban hivatalos kezdőlépését, a brit kormány nyilatkozatát a kétéves kiválási procedúra megindításáról. A korábban megemlített jogi és gazdasági kockázatok azonban nagyban korlátozzák a brit fél valóban kezdeményező magatartását. A brit oldalnak olyan hatékony és szakmailag megalapozott tárgyalási stratégiát kellene találnia, amely lehetővé teheti számára a kezdőlépés előnyének kihasználását.

Talán ígéretes brit opció lehet a macskastratégia egy sajátos változata: a brexit folyamatának elnyújtása minél hosszabb időn át, és az EU összes tagállama támogatásának 
megszerzése a tárgyalások két éven túli folytatására. Ezt a stratégiát persze megfelelően kommunikálni is kellene a tántoríthatatlan brexitpártiság hangsúlyozásával, és elhallgatva a valódi szándékot, a „harmadik állapot” minél további fenntartását. Mintha a brexit folyamata olyan repülögép pályája lenne, amely a szokásos módon felszállt, de sohasem szeretne földet érni (és természetesen lezuhanni sem). Sem élő, sem holt, akár a Schrödinger-féle macska.

\section{Hivatkozások}

BANK OF ENGLAND [2015]: EU Membership and the Bank of England. London.

Blockmans, S.-Emerson, M. [2016]: Brexit's Consequences for the UK - and the EU. Centre for European Policy Studies, Brüsszel.

Blockmans, S.-WeIss, S. [2016]: Estrangement Day: The Implications of Brexit for the EU. Centre for European Policy Studies, Brüsszel.

Booth, S.-Howarth, C.-Persson, M.-Ruparel, R.-Swidlicki, P. [2015]: What if...? The Consequences, Challenges and Opportunities Facing Britain Outside EU. Report 03/2015, Open Europe, London.

Buckle, R.-Hewish, T. [2015]: Old Links, New Ties - Global Free Trade through the Anglosphere and Commonwealth. Megjelent: Buckle és szerzőtársai [2015] 112-145. o.

Buckle, R.-Hewish, T.-Hulsman, J. C.-Mansfield, I.-Oulds, R. [2015]: Directions for Britain Outside the EU. The Institute of Economic Affairs, London.

DE Vries, C.-Hoffmann, I. [2016]: Keep Calm and Carry on. What Europeans Think about a Possible Brexit. Bertelsmann Stiftung, Gütersloh.

Edwardes, M. [1983]: Back from the Brink. Collins, London.

Emerson, M. [2016a]: Brexit - A Last Testament. Centre for European Policy Studies, Brüsszel.

Emerson, M. [2016b]: The Final Brexit Question. The Known Plan A to Remain or the Unknown Plan B to Leave. CEPS Working Document, No. 418. Centre for European Policy Studies, Brüsszel, 418 o.

ERnst And Young LLP [2016]: Helping Boards Assess and Prepare for the UK Referendum on EU Membership. London.

Forgács IMre [2016]: A Brexit előnyei - avagy miért van szükség költségvetési unióra? KözGazdaság Tudományos Füzetek. 11. évf. 3. sz. 11-24. o.

Hofstadter, D. R. [1985]: Metamagical Themas: Questing for the Essence of Mind and Pattern. Penguin Books, Harmondsworth.

Hulsman, J. C. [2015]: Reviving the Age of Drake: How a Global Free Trade Alliance (GFTA) Could Transform the UK. Megjelent: Buckle és szerzőtársai [2015] 146-161. o.

Irwin, G. [2015]: BREXIT: The Impact on the UK and the EU. Global Counsel, London. https://www.global-counsel.co.uk/sites/default/files/special-reports/downloads/Global $\% 20$ Counsel_Impact_of_Brexit.pdf.

Kierzenkowski, R.-Nigel Pain, N.-Rusticelli, E.-Zwart, S. [2016]: The Economic Consequences of Brexit: A Taxing Decision. OECD Economic Policy Paper, 16.

Krugman, P.-Obstfeld, M.-Melitz, M. [2015]: International Trade: Theory and Practice. 9. kiadás, Pearson Education Ltd.

Lannoo, K. [2016]: Brexit and the City. Centre for European Policy, Brüsszel. 
Łazowski, A. [2016]: Procedural Steps towards Brexit. Centre for European Policy, Brüsszel. LidDlE, R. [2015]: The Risk of Brexit. Britain and Europe in 2015. Rowman and Littlefield International Ltd., London.

Mansfield, I. [2015]: A Blueprint for Britain: Openness not Isolation. Megjelent: Buckle és szerzötársai [2015] 1-58. o.

McFadden, P.-Tarrant, A. [2015]: What would 'Out' Look like? Policy Network, London. Medvegyev Péter [2016]: A brexit-szavazás és a nagy számok törvénye. Statisztikai Szemle, 94. évf. 10. sz. 1050-1055. o.

Ottaviano, G. I. P.-Pessoa, J. P.-Sampson, T.-Van Reenen, J. [2014]: Brexit or Fixit? The Trade and Welfare Effects of Leaving the European Union. Centre for Economic Performance Policy Analysis (CEPPA), http://cep.lse.ac.uk/pubs/download/pa016.pdf.

Oulds, R. [2015]: Britain's Post-EFTA Future and EFTA Plus. Megjelent: Buckle és szerzötársai [2015] 59-111. o.

Springford, J.-Whyte, P. [2014]: The Consequences of Brexit for the City of London. Centre for European Reform, London.

Stokes, B. [2016]: Euroskepticism Beyond Brexit. Significant Opposition in Key European Countries to an Ever Closer EU. Pew Research Center, Washington.

TheCityUK [2015]: EU Reform. Time for Change. TheCityUK, London.

Weiss, S.-Blockmans, S. [2016]: The EU Deal to Avoid Brexit: Take it or Leave. Centre for European Policy Studies Special Report, 131. 